\title{
PKM PELATIHAN MENGHITUNG ANGGARAN BIAYA BANGUNAN KEPADA TIM TPK DANA DESA DAN TUKANG DI DESA WANGA AMONGENA KECAMATAN MOTOLING TIMUR KABUPATEN MINAHASA SELATAN
}

\author{
Fransiscus L. P. J. Lumape ${ }^{1}$, Morris S. S. S. Tumanduk ${ }^{2}$ \\ 1 Jurusan Pendidikan Teknik Bangunan, Fakultas Teknik, Universitas Negeri Manado \\ Email: lupapejani11@gmail.com \\ 2 Jurusan Pendidikan Teknik Bangunan, Fakultas Teknik, Universitas Negeri Manado \\ Email: morristumanduk@gmail.com
}

\begin{abstract}
ABSTRAK
Pada umumnya pemahaman Tim Pelaksana Kegiatan (TPK) Dana Desa, Tukang, dan Pemerintah Desa di Kabupaten Minahasa Selatan, dalam menghitung Rencana Anggaran Biaya (RAB) suatu bangunan tidak memahami asas ilmiah dalam analisis dan desain suatu bangunan. Dalam melaksanakan pekerjaan rumah tinggal, Tanggul, Bronjong, Jalan Setapak, dll, biasanya besarnya harga pekerjaan hanya dilakukan dengan penaksiran. Hal ini dilakukan karena kurangnya pengetahuan para tukang tentang bagaimana cara menghitung anggaran biaya suatu bangunan, misalnya berapa banyaknya bahan bangunan yang akan digunakan dan jumlah tenaga kerja. Akibat kurangnya pengetahuan tersebut, maka dapat mengakibatkan kerugian bagi kedua belah pihak baik pemilik bangunan maupun pelaksana pekerjaan itu sendiri. Pelatihan dilakukan dengan metode ceramah dan demonstrasi. Ceramah digunakan untuk menyampaikan konsep tentang: (a) Tujuan dan fungsi dari pembuatan RAB bangunan, (b) Unsusr-unsur yang terlibat dalam pembangunan, (c) Persiapan pelaksanaan pekerjaan (Peraturan dan mekanisme IMB), (d) peraturan-peraturan dalam pelaksanaannya untuk mengendalikan jalannya pekerjaan, dan (e) Menyusun RAB bangunan. Demontrasi dilakukan oleh tim pengabdi sebagai narasumber, yaitu dengan memberikan contoh cara membuat dan menghitung RAB bangunan. Hasil pelaksanaan kegiatan pengabdian dapat disimpulkan bahwa: (1) kegiatan pengabdian dapat meningkatkan pengetahuan tentang teknik perancangan dan analisis anggaran biaya suatu bangunan, dan (2) untuk lebih meningkatkan pengetahuan cara mengatasi permasalahan dalam perancangan dan analisis anggaran biaya suatu bangunan. Kegiatan pengabdian secara keseluruhan dapat dinilai baik dilihat dari 4 (empat) komponen, yaitu: keberhasilan target jumlah peserta pelatihan (104\%), ketercapaian tujuan pelatihan (80\%), ketercapaian target materi yang telah direncanakan (80\%), dan kemampuan peserta dalam penguasaan materi $(60 \%)$.
\end{abstract}

Kata kunci: Pelatihan, Teori Menghitung RAB, Tim Pelaksana Kegiatan (TPK) Dana Desa, Tukang, Pemerintah Wanga Amongena. 


\section{PENDAHULUAN}

Pada umumnya pemahaman Tim Pelaksana Kegiatan (TPK) Dana Desa, Tukang, dan Pemerintah Desa di Kabupaten Minahasa Selatan, dalam menghitung Rencana Anggaran Biaya (RAB) suatu bangunan tidak memahami asas ilmiah dalam analisis dan desain suatu bangunan. Dalam melaksanakan pekerjaan rumah tinggal, Tanggul, Bronjong, Jalan Setapak, dll, biasanya besarnya harga pekerjaan hanya dilakukan dengan penaksiran. Hal ini dilakukan karena kurangnya pengetahuan para tukang tentang bagaimana cara menghitung anggaran biaya suatu bangunan, misalnya berapa banyaknya bahan bangunan yang akan digunakan dan jumlah tenaga kerja. Akibat kurangnya pengetahuan tersebut, maka dapat mengakibatkan kerugian bagi kedua belah pihak baik pemilik bangunan maupun pelaksana pekerjaan itu sendiri.

Hal tersebut juga terjadi pada Tim Pelaksana Kegiatan (TPK) Dana Desa, dan Tukang di Desa Wanga Amongena, Kecamatan Motoling Timur Kabupaten Minahasa Selatan. Dimana banyak rehabilitasi dan pembangunan di desa baik rumah tinggal, Tanggul, Bronjong, Jalan Setapak, dll, dilaksanakan tanpa perencanaan yang matang.

Untuk mengatasi permasalahan di atas dan sebagai bentuk tanggungjawab dosen dalam melaksanakan tridarma perguruan tinggi, Universitas Negeri Manado melalui Lembaga Penelitian dan Pengabdian kepada Masyarakat (LPPM), merupakan suatu lembaga yang dapat memfasilitasi beberapa kegiatan sebagai upaya untuk mengatasi permasalahan dimasyarakat, seperti pemberian program ketrampilan kecakapan hidup (life skills). Program seperti life skills tersebut menjadi hal penting dan relevan untuk dilakukan pada masyarakat.

Pemerintah Desa Wanga Amongena bekerja sama dengan LPPM UNIMA, sebagai upaya memberi ketrampilan yang lebih modern khususnya menghitung rencana anggaran biaya suatu bangunan, dan sebagai upaya meningkatkan pengetahuan tentang teknik perancangan dan analisis anggaran biaya suatu bangunan. Kegiatan ini juga diharapkan dapat meningkatkan pendapatan ekonomi keluarga dan masyarakat di Desa Wanga Amongena Kecamatan Motoling Timur.

Manfaat pelatihan ini adalah engan memberikan pemahaman dan pelatihan kepada tukang Bangunan di Desa Wanga Amongena Kecamatan Motoling Timur Kabupaten Minahasa Selatan, dapat memahami tentang teknik perancangan dan analisis anggaran biaya suatu bangunan.

Pelatihan ini mempunyai beberapa tujuan antara lain:

1. Sebagai upaya memberi ketrampilan yang lebih modern khususnya menghitung rencana anggaran biaya suatu bangunan,

2. Meningkatkan pengetahuan tentang teknik perancangan dan analisis anggaran biaya suatu bangunan.

\section{TINJAUAN PUSTAKA}

Rencana Anggaran Biaya (RAB) adalah perhitungan banyaknya biaya yang diperlukan untuk bahan dan upah, serta biaya-biaya lain yang berhubungan dengan pelaksanaan bangunan atau proyek tertentu.

Anggaran biaya adalah harga dari bangunan yang dihitung dengan teliti, cermat dan memenuhi syarat.

Dalam penyelenggaraan suatu proyek, kegiatan yang akan dihadapi sangat kompleks. Hal ini tentu memerlukan suatu manajemen yang baik sehingga pada akhirnya proyek dapat berjalan sesuai dengan rencana. Maka dari itu diperlukan sekali peraturanperaturan dalam pelaksanaannya untuk mengendalikan jalannya pekerjaan. Diantaranya yaitu

1. Peraturan Tentang Bahan-Bahan Yang Digunakan.

2. Peraturan Tentang Administrasi.

3. Peraturan Tentang Pelaksanaan Pekerjaan Proyek.

4. Undang-Undang Jasa Konstruksi (UU no18 tahun 1999).

5. Undang-Undang K3 (UU 1 tahun 1970) (baru: PP no 50 tahun 2012).

6. Undang-Undang Pengadaan Bahan dan Jasa Konstruksi (baru: PP no 54 tahun 2010.

Estimasi biaya merupakan hal penting dalam dunia industri konstruksi. 
Menurut Pratt (1995) fungsi dari estimasi biaya dalam industri konstruksi adalah untuk:

1. Melihat apakah perkiraan biaya konstruksi dapat terpenuhi dengan biaya yang ada.

2. Mengatur aliran dana ketika pelaksanaan konstruksi sedang berjalan.

3. Kompentesi pada saat proses penawaran. Estimasi biaya berdasarkan spesifikasi dan gambar kerja yang disiapkan owner harus menjamin bahwa pekerjaan akan terlaksana dengan tepat dan kontraktor dapat menerima keuntungan yang layak.

Volume pekerjaan adalah menghitung jumlah banyaknya volume pekerjaan dalam satu satuan.

Rumus perhitungan volume adalah panjang $\mathrm{x}$ lebar $\mathrm{x}$ tinggi (m3).

\section{METODE PELAKSANAAN}

\subsection{Metode Kegiatan Pelatihan}

Metode kegiatan pelatihan adalah mengundang pemerintah setempat, tokohtokoh masyarakat, tukang Bangunan di Desa Wanga Amongena Kecamatan Motoling Timur Kabupaten Minahasa Selatan dengan memberikan naskah materi dan dipresentasikan lewat LCD.

Adapun prosedur pelatihan adalah persiapan, pembukaan, pemaparan materi, Tanya jawab, latihan-latihan, evaluasi, dan penutupan.

Persiapan: menyiapkan tempat pelatihan, naskah materi, LCD, dan mengundang Pemerintah Desa, Pemerintah Kecamatan, serta tokoh-tokoh masyarakat Desa Wanga Amongena.

Pembukaan: yang akan membuka kegiatan pelatihan adalah Kepala Desa Wanga Amongena.

Pemaparan Materi: yang akan memaparkan materi adalah pelatih dengan menggunakan metode ceramah.

Tanya Jawab: Peserta pelatihan diberikan kesempatan bertanya kepada pelatih dan pelatih menjawab pertanyaan peserta.

Latihan-latihan: memberikan pelatihan teknologi perencanaan dan analisis anggaran biaya suatu bangunan.
Evaluasi: memberikan soal tes kepada peserta tentang pemahaman peserta mengenai materi yang sudah diberikan.

Penutupan: rencana penutupan acara kegiatan pelatihan akan ditutup oleh Camat Motoling Timur.

\subsection{Peserta}

Peserta adalah seluruh Tukang, Tim Pelaksana Kegiatan (TPK) Dana Desa, dan Pemerintah Desa Wanga Amongena di Kecamatan Motoling Timur Kabupaten Minahasa Selatan.

\subsection{Lamanya Pelaksanaan Kegiatan Pelatihan}

Pelaksanaan kegiatan pelatihan berlangsung 2 hari dengan waktu efektif selama 16 jam, dan monitoring pelaksanaan pekerjaan bangunan yang sedang dan sementara dikerjakan tukang selama 3 bulan.

\subsection{Tempat dan Waktu Pelaksanaan Kegiatan Pelatihan}

Tempat pelaksanaan kegiatan pelatihan di Gedung Kantor Desa Wanga Amongena Kecamatan Motoling Timur Kabupaten Minahasa Selatan, dan telah dilaksanakan pada Bulan April 2019 sampai Bulan Juni 2019.

\section{HASIL DAN PEMBAHASAN \\ 4.1.Hasil Pelaksanaan Kegiatan PKM}

Hasil pelaksanaan kegiatan PKM secara garis besar dapat dijelaskan sebagai berikut:

1. Langkah awal kegiatan PKM berupa penyampaian usulan pelatihan menghitung Anggaran Biaya Bangunan kepada Bapak Kepala Desa Wanga Amongena, diterima dengan baik. Dengan demikian masyarakat di lokasi pengabdian siap menerima tim PKM Unima untuk melaksanakan kegiatan pelatihan di wilayahnya.

2. Jadwal pelatihan dilaksanakan selama 2 (dua) hari. Pelaksanaan pelatihan pertama, yaitu hari Senin, tanggal 20 April 2019, sedangkan pelaksanaan pelatihan kedua, yaitu hari Senin, tanggal 11 Mei 2019.

3. Pembahasan materi pelatihan oleh tim pengabdi menyepakati bahwa pada hari pertama dilakukan pelatihan dengan metode ceramah dan menggunakan media berupa makalah. Ada 5 (lima) 
materi yang disampaikan kepada peserta pelatihan, Pengertian Rencana Anggaran Biaya, Unsur-Unsur Yang Terlibat Dalam Pembangunan, Persiapan Pelaksanaan Pekerjaan, Pereturan-Peraturan Pelaksanaan dan Menyusun Rencana Anggaran Biaya. Penyampaian materi dilakukan oleh tim PKM Unima dan Pegawai Kecamatan Motoling Timur. Pada hari kedua dilakukan pelatihan dengan metode demonstrasi dengan media berupa cara perhitungan RAB dengan cepat memakai program Exel dan dilanjutkan oleh peserta pelatihan di bawah petunjuk narasumber.

4. Pelaksanaan pelatihan terhadap masyarakat di lokasi pengabdian, yaitu:

a. Pelaksanaan pelatihan pertama pada hari Jumat, tanggal 20 April 2019 di Kantor Desa Wanga Amongena dihadiri oleh 23 orang peserta. Hal ini menunjukkan antusiasme masyarakat di lokasi pengabdian cukup besar dengan program pengabdian dari tim PKM Unima.

b. Materi pelatihan semuanya dapat disampaikan oleh tim PKM Unima, meskipun tidak disampaikan secara detil.

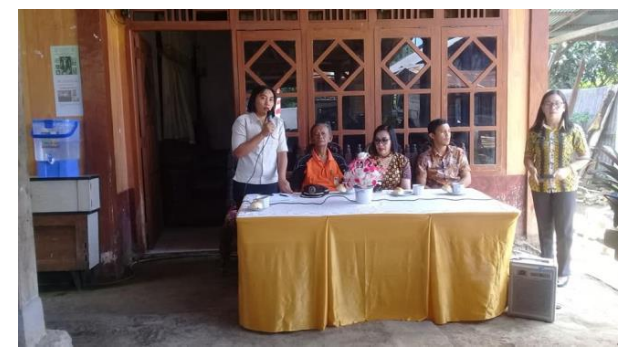

Gambar 4.1 Sekdes Wanga Amongena Memberikan Sambutan dan Membuka Kegiatan Pelatihan.

c. Kemampuan peserta pelatihan dalam penguasaan materi cukup baik, hal ini dapat dilihat dari antusiasme peserta dalam sesi diskusi dan tanya jawab seperti pada Gambar 4.2. Beberapa pertanyaan yang diajukan oleh peserta, antara lain: (1) bagaimana menentukan harga bahan bangunan, (2) bagaimana cara menghitung cepat volume pondasi talud, bagaimana teknik menghitung $\mathrm{RAB}$ bangunan agar tidak Overlap, (4) langkah mudah, sederhana, dan tepat dalam menghitung RAB perencanaan air bersih, dan (5) halhal yang perlu segera dilakukan jika terjadi Overlap anggaran biaya bangunan.

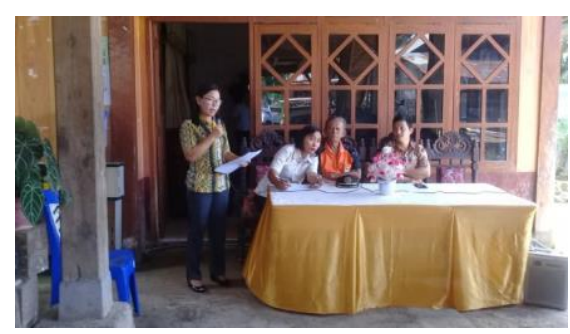

Gambar 4.2. Peserta Memberikan Pertanyaan kepada Tim PKM Unima.

d. Pelaksanaan pelatihan pertama berjalan lancar sesuai rencana, sehingga diharapkan kegiatan pengabdian dapat meningkatkan pengetahuan dan kesadaran masyarakat tentang teknik perhitungan RAB bangunan.

e. Pelaksanaan pelatihan kedua pada hari Sabtu, tanggal 11 Mei 2019. Kegiatan tersebut juga dihadiri 26 orang peserta.

f. Monitoring kegiatan oleh tim pengabdi dilakukan pada hari Sabtu, tanggal 6 Juli 2019 dengan mendatangi desa wanga amongena mendampingi menghitung RAB dana desa tahun 2019.

g. Pelaporan kegiatan pengabdian dilakukan secara tertulis kepada LPPM Unima. Sebelum pengumpulan laporan akhir PKM dilakukan kegiatan seminar akhir untuk mendapatkan beberapa masukan perbaikan laporan oleh teman sejawat.

\subsection{Pembahasan Hasil Pelaksanaan Kegiatan PKM}

Hasil pelaksanaan kegiatan PKM secara garis besar dapat dilihat dari penilaian beberapa komponen sebagai berikut:

1. Keberhasilan target jumlah peserta pelatihan Keberhasilan target jumlah peserta pelatihan dapat dinilai sangat baik, mengingat target jumlah peserta pelatihan sebanyak 20 orang, sementara itu dalam pelaksanaan kegiatan pelatihan baik hari pertama maupun kedua yang dapat hadir juga sebanyak 26 orang (104\%).

2. Ketercapaian tujuan pelatihan

Keterbatasan waktu yang disediakan mengakibatkan tidak semua materi dapat 
disampaikan secara detil. Banyak di antara materi yang hanya disampaikan secara garis besar, sehingga sangat memungkinkan peserta dengan latar belakang pendidikan berbeda masih kurang paham dengan materi yang diberikan oleh tim pengabdi. Kegiatan tersebut dilanjutkan dengan demonstrasi cara perhitungan RAB dengan cepat memakai program Exel di lokasi pengabdian pada waktu lain. Dilihat dari antusiasme peserta dalam forum diskusi dan tanya jawab serta pelaksanaan demonstrasi maka ketercapaian tujuan pelatihan dapat dinilai baik $(80 \%)$, hal ini dikarenakan adanya peningkatan pengetahuan dan kesadaran dari peserta terhadap cara perhitungan RAB bangunan.

3. Ketercapaian target materi yang telah direncanakan.

Ketercapaian target materi yang telah direncanakan dapat dinilai baik (80\%) karena materi pelatihan telah dapat disampaikan secara keseluruhan meskipun tidak secara detil akibat keterbatasan waktu. Materi pelatihan yang telah disampaikan adalah: Pengertian Rencana Anggaran Biaya, Unsur-Unsur Yang Terlibat Dalam Pembangunan, Persiapan Pelaksanaan Pekerjaan, Pereturan-Peraturan Pelaksanaan dan Menyusun Rencana Anggaran Biaya.

\section{KESIMPULAN}

Berdasarkan hasil ketercapaian pelatihan, maka dapat ditarik beberapa kesimpulan sebagai berikut ini:

1. Kegiatan pengabdian dapat meningkatkan pengetahuan dan kesadaran masyarakat tentang teknik perhitungan RAB bangunan.

2. Peningkatan pengetahuan dan ketrampilan masyarakat dilakukan dengan penyampaian materi, antara lain: (a) Pengertian Rencana Anggaran Biaya, (b) Unsur-Unsur Yang Terlibat Dalam Pembangunan, (c) Persiapan Pelaksanaan Pekerjaan, (d) Pereturan-
Peraturan Pelaksanaan, dan (e) Menyusun Rencana Anggaran Biaya.

3. Untuk lebih meningkatkan pengetahuan dan ketrampilan masyarakat dilakukan penerapan cara perhitungan $\mathrm{RAB}$ bangunan dengan cepat memakai program Exel.

\section{UCAPAN TERIMA KASIH}

1. Kepada Prof. Dr. Julyeta P.A. Runtuwene, M.S, DEA sebagai Rektor Universitas Negeri Manado yang telah mendanai PKM ini.

2. Kepada Prof. Dr. Revolson A. Mege, M.S., sebagai Kepala LPPM UNIMA yang telah memberikan motivasi dan rekomendasi sehingga PKM ini dapat dilaksanakan.

\section{REFERENSI}

Andie A. Wicaksono, 2009, Kreasi, Tipe \& Solusi Menciptakan Rumah Sehat, Penerbit Penebar Swadaya, Jakarta.

Departemen Pekerjaan Umum, 2002, Brosur-Brosur Penyuluhan Perumahan, Penerbit P.U. Jakarta.

Frick, Hein, 2001, Ilmu Konstruksi Bangunan 2, Penerbit Kanisius, Yogyakarta

Imam Subarkah, Ir, 1988. Konstruksi Bangunan Gedung, Penerbit Idea Dharma, Bandung.

John W.N., 1992. Rencana Anggaran Biaya Bangunan, Penerbit CV. Asona Jakarta.

Sri Hadiarti, Ir, 2000, Rumah dan Lingkungan yang Sehat, Penerbit Majalah Cipta Nomor 98, Jakarta. 